\title{
Bizygomatic Width and Personality Traits of the Relational Field
}

\author{
Ancho Bizigomático y Rasgos de Personalidad del Campo Relacional
}

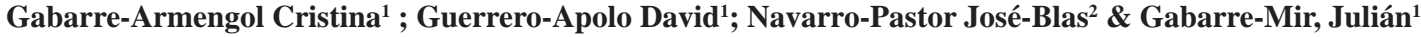

\begin{abstract}
GABARRE-ARMENGOL, C.; GUERRERO-APOLO, D.; NAVARRO-PASTOR, J. B. \& GABARRE-MIR, J. Bizygomatic width and personality traits of the relational field. Int. J. Morphol., 37(1):184-189, 2019.

SUMMARY: The bizygomatic width when compared to the bigonial width (WD) has been proposed as a craniofacial marker of some social and personality traits, such us self-reliance or the ability to express emotions. However, no studies have examined the association between WD and psychopathic traits, as happens with other craniofacial variables such us the facial width-to-height ratio (fWHR). In a sample of 70 adults (male and female) we took measures of the bizygomatic and the bigonial arches. Subjects performed self-assessment tests to evaluate their self-reliance, their alexithymia and emotional expressiveness and their coldheartedness or callousunemotional. Results showed a significant relationship between WD and self-reliance, emotional expression and alexithymia, and a tendency towards significance with general psychopathic scores. Additionally, we found a modificatory effect of the variables sex and age when analyzing the influence of the WD on the Factor 3 - "Coldheartedness" of the Psychopathic Personality Inventory-Revised (PPI-R), where this effect diminished depending on the subject's sex and age. Results suggested that the WD seem to be a good marker to be taken into consideration in further research that examines craniofacial traits and personality traits of the socio-emotional field.
\end{abstract}

KEY WORDS: Face; Bizygomatic arch; Alexithymia; Psychopathy; Callous-Unemotional.

\section{INTRODUCTION}

There is a growing interest in the study of the face as an indicator of its function; it's the most distinctive zone of the body and it has a specific interaction with the environment. It contains the main organs of the senses with which an individual keeps itself updated. The face also has a direct relationship with its environment and with the brain, which is the centre of information processing, control and coordination of physiological, emotional and psychological processes. This is seen in the interconnected and synchronized development of the face and brain (Richtsmeier \& Flaherty, 2013).

The traditional focus of this relationship is been studied from the perspective of the syndromes, where face and brain are affected at the same time (Jones, 2007), as evidenced by disorders such as schizophrenia (Lin et al., 2015) or bipolar disorder (Hennessy et al., 2010). Regarding specific facial variables, fWHR is one of the most studied, with evidence that linked it with leadership in both competitive and prosocial environments (Hahn et al., 2017), integrity (Ormiston et al., 2017), sexual desire, sociosexuality and fidelity intention (Arnocky et al., 2017) and some psychopathic personality traits such as boldness, dominance, egocentricity impulsivity and general psychopathic scores (Anderl et al., 2016). There are other facial variables that have yielded significant results such as the inclination of the forehead and impulsivity (Guerrero et al., 2016; Guerrero-Apolo et al., 2018a) and the volume of gray matter in certain areas of the cortex (Guerrero-Apolo et al., 2018b), age, testosterone and strength with the lower/full face ratio, cheekbone prominence and fWHR-lower (Hodges-Simeon et al., 2016), or the difference of widths between bizygomatic and bigonial arches with traits such as self-reliance and the ability/ impairment to express and feel emotions (Gabarre-Mir $e t$ al., 2017). This impairment to express or feel emotions could be explained by the deficit in emotional information processing hypothesis. Since Cleckley's description (Cleckley, 1976), various hypotheses have attempted to explain the etiological mechanisms underlying psychopathy. The two main lines that study the construct have been integrated into the two factors that constitute the Hare Psychopathy Checklist-Revised (PCL-R; Hare, 1991): hypothesis of the deficit in emotional information

\footnotetext{
${ }^{1}$ Institute of Craniofacial Psychology, Barcelona, Spain.

${ }^{2}$ Department of Psychobiology and Methodology, Universitat Autònoma de Barcelona, Bellaterra, Spain.
} 
processing (processing of affective information and absence of fear, collected in Factor 1: "Interpersonal / Affective" of the PCL-R), and response modulation hypothesis (modulation of the response, collected in Factor 2: "Social deviation"). Several authors (Blair et al., 2005) have differentiated aggressiveness in: 1) Reactive, characteristic of the Antisocial Personality Disorder, where threatening frustration or stimulus triggers aggression (without concrete potential goal), and 2) Instrumental, where aggression has the purpose of achieving a specific target. Reactive aggressiveness, more akin to impulsivity and Factor 2 of the PCL-R, is not one of the objectives of this research. On the other hand, psychopathy includes a non-homogeneous group of individuals. Cleckley defended the idea that a poor interpersonal and affective life was the central core of psychopathy and that individuals with psychopathic characteristics were distributed throughout the general population where "successful psychopaths" are able to optimize their affective coldness to make more objective decisions, a common profile in high social positions (doctors, scientists, CEOs, etc.).

The aim of this study is to study, in the general population, the relationship of the difference between the bizygomatic and bigonial width (width difference WD) and psychological characteristics, such as: 1) self-reliance, 2) the ability to describe, exhibit and express emotions; and 3) coldheartedness.

\section{MATERIAL AND METHOD}

The present study meets all ethical standards and has been approved by the University Ethical Committee (CEEAH - Universitat Autònoma de Barcelona).

Participants and procedure. All the subjects voluntarily attended the study, in response to an advertisement published in a local newspaper. Initially, only male participants were to be included in the study. However, the number of voluntary male participants was relatively small, and it was decided to include an additional female sample matched by age with the male sample. Finally, the sample is composed of adult participants $(\mathrm{N}=70)$, men $(84 \%)$ and women $(16 \%)$ from the general population. The participants were informed of the study process by means of a fact sheet and signed the informed consent document, agreeing to participate in the study that included tests, photographs and measurements for exclusive research purposes. The participants obtained a remuneration 50 after completing all the phases of the procedure.

Anthropometric measures. Measurements were made of the bizygomatic arch (AZ) and the bigonial arch (AG), following the methodology of Gabarre-Mir et al. To establish the degree of retraction - expansion of $A Z$, we took $A G$ and subtracted AZ; the resulting measurement was called WD (Width difference) Fig. 1.

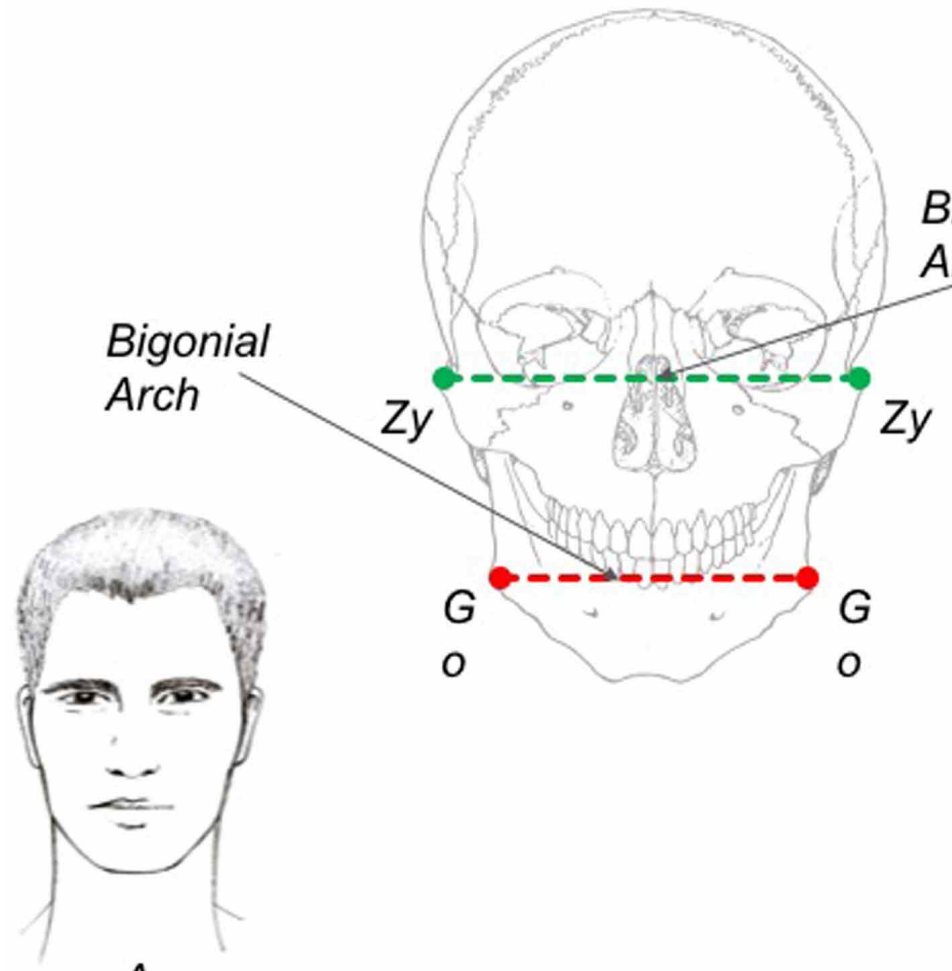

$A$ 
Instruments of psychological evaluation. Five psychometric tests were used:

A) Self-reliance was evaluated with the two forms (A and B) of the Q2 Factor of the Sixteen Personality Factor Questionnaire (16PF, Spanish validation of TEA of Seisdedos et al., 1989), a 20-item self-report measure, 10 for each form, using a Likert type scale (0 to 2 ), with a minimum scoring of 0 and a maximum of 40 . Low scoring defined grouporiented, affiliative, a joiner and follower dependent subjects. High scoring defined self-reliant, solitary, resourceful, individualistic and self-sufficient subjects. The internal consistency of the Spanish validation of the 16pf was 0.520.78 . For our study it was 0.74 .

B) In order to broadly asses the ability to express and describe emotions, 3 instruments were used:

A) Scale of Emotional Expressivity (EES) (Kring, et al., 1994; a = 0.91), a 17-item self-reported measure using a Likert type scale of 6 points, with a range of scores from 17 to 102 . This scale assessed the emotional expressiveness via expressions, vocalizations or gestures.

B) Toronto Alexithymia Scale (TAS-20, Spanish validation of Moral de la Rubia \& Retamales, 2000), a 20-item selfreported measure using a Likert type scale of 5 points, with a range of scores from 20 to 100 . This scale assessed the presence/absence of alexithymia, with core characteristics marking dysfunction in emotional awareness, social attachment, and interpersonal relating. For the interpretation of the TAS-20, the authors indicate that scores $\leq 51$ show the absence of alexithymia, between 52 and 60 show possible alexithymia and $\geq 61$ show alexithymia. Cronbach's Alpha for the Spanish validation was 0.71 .

C) The Alexitimia On-line Questionnaire - (OAQ-G2; Thompson, 2005), a 37-item self-reported measure using a Likert type scale of 5 points, with a range of scores from 37 to 185 . This Questionnaire was used in order to attend limitations observed in other self-informed alexithymia tests (studies of validity are not available yet).

C) Psychopathic traits were evaluated with the Psychopathic Personality Inventory-Revised (PPI-R, developed by Lilienfeld \& Widows, 2005) a 154-item self-report measure using a Likert type scale ( $1=$ false, $2=$ mostly false, $3=$ mostly true, $4=$ true). The PPI-R yields a total score as well as scores on eight content scales grouped in 3 factors: Factor 1 "Self-Centered impulsivity" (Maquiavellian Egocentricity, Rebellious Nonconformity, Blame Externalization, Carefree Nonplanfulness), Factor 2 "Fearless Dominance" (Social Influence, Fearlessness, Stress
Immunity) and Factor 3 " Coldheartedness" (Coldheartedness). It includes three validity scales ("Deviant Responding" measure of aberrant responding/malingering, "Virtuous Responding" measure of socially desirable responding, and "Inconsistent Responding" measure of random or careless responding). Total scores and Factor 3 scores were used. Six "atypical" participants were excluded, following the criteria established by the authors for the exclusion of problematic profiles. Factor 3 was used to evaluate "Coldheartedness". T-score cutoff scores of 65 are commonly used in clinical practice as markers of scores that are significantly elevated. (PPI-R: $a=0.91$; Factor $3 \mathrm{a}=$ 0.79 ; in the presented study 0.99 y 0.78 , respectively).

Inter-judges evaluation. To estimate the accuracy of the human visual evaluation of the WD, a system of assessment of the morphological width of the bizygomatic arch was established with a scale of scores following the methodology of Gabarre-Mir et al. The visual evaluation of the WD was carried out independently by 5 judges with specialized training (15 hours) in measuring the bizygomatic width. They did not know the objective of the research, nor the study subjects, nor did they know each other.

Statistical analysis. The statistical analysis was done with SPSS 19 (2010). Apart from the usual descriptive analysis of all the variables collected, to analyse the influence of WD on personality variables, multiple linear regression models were estimated. The possible modifier role of sex and age was evaluated, and, in absence of statistically significant interactions, it was analysed whether both demographic variables were necessary as adjustment terms. When the change between raw and adjusted coefficient was greater than 10 $\%$, adjusted model was preferred.

The analysis for the visual evaluation of the WD included, in the first place, the study of the agreement between judges by means of the intraclass correlation coefficient for absolute agreement. Second, the Pearson correlation coefficient between visual and anthropometric measurements was calculated.

\section{RESULTS}

Table I presents the descriptive results of the demographic, facial and psychological measures. The mean age (43.3 years) and the wide range that it includes make it possible to make inferences to any adult person. Regarding the WD measure, in the sample there was a slight prevalence towards retraction, since the mean WD is positive. Regarding the psychological measures, the mean of EES (63.4) is very 
Table I. Description of demographical, facial and psychological measures.

\begin{tabular}{lcccc}
\hline $\mathrm{N}=70$ & Mean & SD & Min. & Max. \\
\hline Age & 43.34 & 10.86 & 22.5 & 63.5 \\
WD & 0.74 & 1.46 & -1.55 & 4.0 \\
16PF (Factor Q2) & 22.84 & 7.24 & 7.0 & 38 \\
EES & 63.43 & 17.94 & 24 & 95 \\
TAS-20 & 48.74 & 13.19 & 23 & 77 \\
OAQ-G2 & 98.89 & 18.99 & 57 & 139 \\
PPI-R & 51.91 & 11.11 & 31 & 84 \\
Factor 3 & 46.11 & 10.46 & 30 & 77
\end{tabular}

SD: Standard Deviation; WD: Width difference between bigonial arch (AG) and bizygomatic arch (AZ; WD = AZ - AG) in centimetres; $16 \mathrm{PF}$ (Factor Q2): Self-Reliance; EES: Emotional Expressivity Scale; TAS-20: Toronto Alexithymia Scale; OAQ-G2: Online Alexithymia Questionnaire; PPI-R (T): Psychopathic Personality Inventory-Revised (global score); and PPI-R (Factor 3): Coldheartness.

close to the theoretical mean $($ men $=61.15 \pm 12.69$ and women $=66.6 \pm 12.71)$. For the interpretation of the TAS-20, the mean obtained (48.74) suggests that it is a sample, on average, with low values of alexithymia. On the contrary, when interpreting the mean value of the OAQ-G2 (98.89) we found a sample with values higher than the cut-off point established by the authors (between 95 and 112), which indicates possible alexithymia. For the interpretation of the PPI-R, the authors defined scores 65 as cut-off point, where equal or greater scores indicate clinical values in psychopathy. The mean in the sample studied (51.91) is within non-clinical values.

Table II presents the results of the influence of the WD on the different measures of personality and emotional field. The results showed very significant relationships between WD and the psychological variables studied. Increasing the WD by one centimetre increased the result of $16 \mathrm{PF}$ - Q2 by 3.85 points, by 3.85 points for TAS-20 and by 5.48 points for OAQ-G2, while the score in EES decreased by 7.49 points. All these effects are statistically very significant ( $\mathrm{p}<.0005)$ with $95 \%$ confidence intervals clearly far from a value of 0 . In the influence of the WD on the scores of the PPI-R a tendency towards significance is observed $(p=.065)$, where higher scores on WD (higher retraction of AZ) tend to be related to more psychopathic traits.

Finally, when analysing the influence of WD on Factor 3 of the PPI-R inventory, a modifying effect of both sex $(\mathrm{p}=.028)$ and age $(\mathrm{p}=.030)$ was found. Consequently, Table III presents the effect of WD for both sexes and for 3 values representative of age. Since in the sample the age fluctuated between 22 and 63 years, ages 25, 45 and 60 were chosen. The results showed that for both sexes and for different age groups, the effect of WD on Factor 3 is positive, higher in women than in men, and that it decreases with age in a similar way for both sexes, until it became statistically nonsignificant for subjects of 60 years of both sexes and for men with a mean age.

Regarding the agreement between judges, an intraclass correlation coefficient of .976 (95\% CI. 965 to .984) was obtained. The 5 individual assessment were averaged, and the mean value was correlated with the WD, obtaining a Pearson coefficient of .949 (p<.001).

Table II. Influence of the width difference between bigonial arch and bizygomatic arch (WD), and psychological variables.

\begin{tabular}{lccccc}
\hline $\mathrm{N}=70$ & $\begin{array}{c}\text { Interaction WD } \\
\text { by Sex } p\end{array}$ & $\begin{array}{c}\text { Interaction WD } \\
\text { by Age } p\end{array}$ & $\mathrm{~B}$ & $p$ & CI 95\% \\
\hline 16PF (Factor Q2) & .414 & .092 & 3.69 & $<.0005$ & 2.89 to 4.48 \\
EES & .666 & .265 & -7.49 & $<.0005$ & -9.82 to -5.17 \\
TAS-20 & .155 & .302 & 3.85 & $<.0005$ & 1.88 to 5.81 \\
OAQ-G2 & .463 & .163 & 5.48 & $<.0005$ & 2.64 to 8.32 \\
PPI-R** & .135 & .810 & $1.95^{*}$ & .065 & -0.12 to 4.03 \\
Factor 3** & .028 & .030 & 3.69 & $<.0005$ & 2.89 to 4.48 \\
\hline
\end{tabular}

WD: Width difference between arches; 16PF (Factor Q2): Self-Reliance; EES: Emotional Expressivity Scale; TAS20: Toronto Alexithymia Scale; OAQ-G2: Online Alexithymia Questionnaire; PPI-R (T): Psychopathic Personality Inventory-Revised (global score); and PPI-R (Factor 3): Coldheartness. *Adjusted by age and sex. ** $\mathrm{n}=64$

Table III. Influence of the width difference between arches (WD) in the Coldheartness score (PPI-R Factor 3) depending on sex and age.

\begin{tabular}{llccc}
\hline $\mathrm{N}=64$ & & $\mathrm{~B}$ & $p$ & CI $95 \%$ \\
\hline \multirow{2}{*}{25 age } & Women & 12.26 & $<.005$ & 6.03 to 18.49 \\
& Men & 5.41 & .008 & 1.5 to 9.32 \\
\multirow{2}{*}{45 age } & Women & 8.29 & .007 & 2.4 to 14.17 \\
& Men & 1.43 & .131 & -.44 to 3.31 \\
\multirow{2}{*}{60 age } & Women & 5.31 & .131 & -1.62 to 12.24 \\
& Men & -1.54 & .364 & -4.91 to 1.83 \\
\hline
\end{tabular}




\section{DISCUSSION}

The results presented support the relationship between personality and emotional traits studied with the WD.

In concordance with the results of Gabarre-Mir et al. a very significant relationship has been found between high values in WD and high values in self-reliance, individualism and greater resourcefulness. Lower values in WD were related to high values in group-oriented, affiliative and a joiner and follower dependency. Likewise, a very significant relationship has been found between high values in WD and low values in emotional expressivity, as well as high values in the difficulty to verbally express feelings and poor emotional insight (alexithymia). These findings suggest that the WD could be an objective marker of the individual capacity of self-reliance, socio-emotional skills and establishment of relational links with others.

On the other hand, it has been found that high values in WD tend to be related to high values in psychopathic traits. Given that the instrument used for the assessment of psychopathic traits mixes elements of impulsiveness and affective coldness, it was decided to assess Factor 3 of the PPI-R, which assesses Affective Coldness (more akin to instrumental aggressiveness, Factor 1 of the PCL-R and the objectives of our research). The results showed different effects of the WD on "Coldheartedness", according to sex and age, with a stronger effect for the female sex, effect that decreases with age (for the two sexes). This suggests that life experience has an important effect on the modulation of "Coldheartedness" and the ability to establish emotional links with others. The lower significance between WD and the total score of psychopathy could be explained by the fact that this facial anthropometric variable is not related to other psychopathic traits assessed by other scales of the PPI-R (better explained by the response modulation hypothesis and Factor 2 of the PCL-R, see in Introduction).

The results presented here point to the WD as an objective marker of this central nucleus of psychopathy, suggesting that affective coldness interacts with other traits, giving rise to a heterogeneous group with different manifestations according to individual motivations and characteristics. The results seem to defend this concept, given that the WD binomial and affective coldness tend to be distributed uniformly in the general population, being able to act as protective/risk factors for the subject (independent of other personality traits).

As in Gabarre-Mir et al. we provide evidence of a higher prevalence of $\mathrm{AZ}$ retraction in men, which seems to be a characteristic anthropological feature of males. The prevalence found for $\mathrm{AZ}$ retraction during the sampling and according to Gabarre-Mir et al., suggests that this feature is more characteristic in men and, for this reason, its effect may have been greater in women.

Visual evaluation results showed a very high agreement among judges, as well as a high correlation with the WD measure, confirming that it is an observable, fast and reliable method of measuring.

This study is only a partial analysis of the face other facial features can have an important modifying role. In addition, since the functionality of the shape of the face is analogous to the brain, where functions require the interaction of different areas of the brain, it is expected that the face works in the same way. In this sense, further research is advisable using a broader facial model (not the study of a single trait). The sample size is a limitation; the percentage of women included is low making a generalization difficult regarding to the general population. For future studies, we recommend balancing the sample by sex and replicating this study using a larger sample size.

The main addition of this study is the contribution of evidence of WD as an objective marker of individual socio-emotional skills and the breadth of their relational field. Boughner et al. (2008) and Sisodiya (2008), and GuerreroApolo et al. (2018b) observed significant correlations in brain tissue from different areas and facial measurements. Similarly, we propose that the retraction of AZ is related to a lower capacity of the structures it contains, so these areas, mostly related to functions of the affective field, could be volumetrically reduced. We also propose that the narrowing of $\mathrm{AZ}$ could have implications in the connectivity with adjacent more cortical areas interrupting, with this "morphological bottleneck", the fluidity of this connectivity. Future studies that combine the methodology used here with neuroimaging techniques will provide information on this new hypothesis.

GABARRE-ARMENGOL, C.; GUERRERO-APOLO, D.; NAVARRO-PASTOR, J. B. \& GABARRE-MIR, J. Ancho bizigomático y rasgos de personalidad del campo relacional. Int. J. Morphol., 37(1):184-189, 2019.

RESUMEN: La anchura bicigomática en comparación con la anchura bigonial (WD) se ha propuesto como marcador craneofacial de algunos rasgos sociales y de personalidad, como la independencia/gregarismo o la capacidad de expresión emocional. Sin embargo, ningún estudio ha examinado la asociación entre la WD y los rasgos psicopáticos, como ocurre con otras variables craneofaciales, como la ratio anchura / altura facial (fWHR). 
En una muestra de 70 adultos (hombres y mujeres) tomamos medidas de los arcos bizigomático y bigonial. Los sujetos realizaron pruebas de autoevaluación para evaluar la capacidad de incorporarse al grupo, la alexitimia y la expresividad emocional, y la frialdad o la insensibilidad emocional. Los resultados mostraron una relación significativa entre WD con independencia/gregarismo, expresión emocional y alexitimia, así como una tendencia hacia la significación con la psicopatía en general. Adicionalmente, encontramos un efecto modificador de las variables sexo y edad al analizar la influencia de la WD en el Factor 3 - "Coldheartness" del Inventario de Personalidad Psicopática-Revisado (PPI-R), donde este efecto disminuye según sexo y edad. Los resultados sugieren que el WD parece ser un buen marcador para tener en cuenta en futuras investigaciones que examinen los rasgos craneofaciales y los rasgos de personalidad del campo socioemocional.

PALABRAS ClAVE: Cara; Arco bicigomático; Alexitimia; Psicopatía; Frialdad afectiva.

\section{REFERENCIAS BILIOGRÁFICAS}

Anderl, C.; Hahn, T.; Schmidt, A. K.; Moldenhauer, H.; Notebaert, K.; Clément, C. C. \& Windmann, S. Facial width-to-height ratio predicts psychopathic traits in males. Personal. Indiv. Differ., 88:99-101, 2016.

Arnocky, S.; Carré, J. M.; Bird, B. M.; Moreau, B. J. P.; Vaillancourt, T.; Ortiz, T. \& Marley, N. The facial width-to-height ratio predicts sex drive, sociosexuality, and intended infidelity. Arch. Sex. Behav., 47(5):1375-85, 2017.

Blair, J.; Mitchell, D. \& Blair, K. The Psychopath: Emotion and the Brain. Malden, Blackwell Publishing, 2005.

Boughner, J. C.; Wat, S.; Diewert, V. M.; Young, N. M.; Browder, L. W. \& Hallgrímsson, B. Short-faced mice and developmental interactions between the brain and the face. J. Anat., 213(6):646-62, 2008.

Cleckley, H. M. The Mask of Sanity. $5^{\text {th }}$ ed. St. Louis, Mosby, 1976.

Gabarre-Mir, J.; Navarro-Pastor, J. B.; Gabarre-Armengol, C. \& EstaúnFerrer, S. Bizygomatic width and its association with social and personality traits in males. Int. J. Morphol., 35(3):1037-42, 2017.

Guerrero-Apolo, J. D.; Navarro-Pastor, J. B.; Bulbena-Vilarassa, A. \& Gabarre-Mir, J. The slant of the forehead as a craniofacial feature of impulsiveness. Bras J.. Psychiatry, 40(3):270-6, 2018a.

Guerrero-Apolo, J. D.; Navarro-Pastor, J. B.; Bulbena-Vilarassa, A. \& Gabarre-Mir, J. Association between self-reported impulsiveness and gray matter volume in healthy adults. An exploratory MRI study. Neurosci. Lett., 674:112-6, 2018b.

Guerrero, D.; Gabarre-Armengol, C.; Navarro, J. B. \& Gabarre-Mir, J. Impulsivity and its association with the slant of the forehead. Int. J. Morphol., 34(3):990-6, 2016.

Hahn, T.; Winter, N. R.; Anderl, C.; Notebaert, K.; Wuttke, A. M.; Clément, C. C. \& Windmann, S. Facial width-to-height ratio differs by social rank across organizations, countries, and value systems. PLoS One, 12(11):e0187957, 2017.

Hare, R. D. Hare Psychopathy Checklist-Revised. Toronto, MultiHealthSystems, 1991

Hennessy, R. J.; Baldwin, P. A.; Browne, D. J.; Kinsella, A. \& Waddington, J. L. Frontonasal dysmorphology in bipolar disorder by 3D laser surface imaging and geometric morphometrics: comparisons with schizophrenia. Schizophr. Res., 122(1-3):63-71, 2010.

Hodges-Simeon, C.; Sobraske, K.; Samore, T.; Gurven, M. \& Gaulin, S. Facial Width-to-Height Ratio (fWHR) is not associated with adolescent testosterone levels. PLoS One, 11(4):e0153083, 2016.
Jones, K. L. Patrones Reconocibles de Malformaciones Humana. $6^{\text {th }}$ ed. Madrid, Elsevier Saunders, 2007.

Kring, A. M.; Smith, D. A. \& Neale, J. M. Individual differences in dispositional expressiveness: development and validation of the Emotional Expressivity Scale. J. Pers. Soc. Psychol., 66(5):934-49, 1994.

Lilienfeld, S. O., \& Widows, M. R. Psychopathic Personality Inventory Revised. Professional Manual. Lutz, PAR, 2005.

Lin, A. S.; Chang, S. S.; Lin, S. H.; Peng, Y. C.; Hwu, H. G. \& Chen, W. J. Minor physical anomalies and craniofacial measures in patients with treatment-resistant schizophrenia. Psychol. Med., 45(9):1839-50, 2015.

Moral de la Rubia, J. \& Retamales, R. Estudio de validación de la Escala de Alexitimia de Toronto (TAS-20) en muestra española. Rev. Electron. Psicol., 4(1):art3, 2000. Available from: http://www.psiquiatria.com/ psicologia/vol4num1/art_3.htm).

Ormiston, M. E.; Wong, E. M. \& Haselhuhn, M. P. Facial-width-to-height ratio predicts perceptions of integrity in males. Personal. Indiv. Differ., 105:40-2, 2017.

Richtsmeier, J. T. \& Flaherty, K. Hand in glove: brain and skull in development and dysmorphogenesis. Acta. Neuropathol., 125(4):46989, 2013.

Seisdedos, N.; Cordero, A.; González, M. \& De la Cruz, M. V. 16 PF, Cuestionario Factorial de Personalidad: Adaptación Española. Madrid, TEA Ediciones, 1989.

Sisodiya, S. Brain structure, function, and genetics revealed by studies of the eye and face. Curr. Opin. Neurol., 21(4):404-9, 2008.

SPSS Inc. Package for Social Sciences 19.0.0. New York, IBM, 2010.

Thompson, J. Emotionally Dumb: An introduction to Alexithymia. On-line Alexithymia Questionnaire (OAQ-G2). 2005. Available from: http:// espectroautista.info/OAQ-es.html

\section{Corresponding author: \\ Cristina Gabarre-Armengol \\ Institute of Craniofacial Psychology \\ Barcelona \\ SPAIN}

Email: info@craniofacialpsychology.com

Received: 31-07-2018

Accepted: 20-11-2018 